\title{
ANALISIS KESALAHAN EJAAN PADA KARANGAN MAHASISWA FAKULTAS EKONOMI DAN BISNIS UIN SYARIF HIDAYATULLAH JAKARTA
}

\author{
Didah Nurhamidah \\ Program Studi Sastra Indonesia, Fakultas Sastra, Universitas Pamulang \\ dosen01187@unpam.ac.id
}

\begin{abstract}
ABSTRAK
Huruf kapital dan tanda baca merupakan bagian dari komponen ortografi yang harus diperhatikan di dalam tulisan. Berdasarkan pengalaman penulis, terdapat kesalahan penggunaan huruf kapital dan tanda baca yang dilakukan mahasiswa saat belajar bahasa Indonesia ketika menulis karangan mahasiswa. Kesalahan ini tidak disadari karena lebih terfokus pada isi tulisan dibandingkan dengan cara penulisannya. Akibatnya, tidak jarang mahasiswa melakukan kesalahan pada penggunaan huruf kapital dan tanda baca dalam bahasa Indonesia. Tujuan penelitian ini adalah untuk mendeskripsikan kesalahan ejaan pada penggunaan huruf kapital dan tanda baca dalam karangan mahasiswa, jenis-jenis kesalahan yang dilakukan serta mengetahui faktor-faktor penyebab kesalahan tersebut. Metode yang digunakan dalam penelitian ini adalah deskriptif analisis. Hasil penelitian menunjukkan bahwa terdapat 26 kesalahan yang terdiri dari 17 kesalahan penggunaan huruf kapital dan 9 kesalahan penggunaan tanda baca yang dilakukan oleh mahasiswa dalam karangan. Kesalahan penggunaan huruf kapital paling banyak terdapat pada jenis penggunaan huruf kapital untuk menunjukkan kata tempat, penggunaan tanda baca paling banyak dilakukan mahasiswa pada enggunaan tanda titik (.) dan tanda koma (,). Dari hasil penelitian tersebut disarankan agar mahasiswa mempelajari lebih dalam serta meningkatkan frekuensi latihan tentang aturan penggunaan huruf kapital dan tanda baca bahasa Indonesia.
\end{abstract}

Kata Kunci: penggunaan huruf, tanda baca, kesalahan berbahasa

\section{PENDAHULUAN}

$\mathrm{B}$ ahasa merupakan unsur yang sangat penting dalam kehidupan manusia. Bahasa digunakan untuk mengutarakan dan menerima pikiran serta perasaan manusia. Dengan mempelajari bahasa, kita berharap dapat lebih memahami bagaimana pikiran manusia menghasilkan dan memproses bahasa tersebut. Jika dilihat dari fungsinya, bahasa digunakan sebagai alat komunikasi yang menyampaikan pikiran, perasaan, hasrat, dan kehendak pada orang lain. Untuk itu penguasaan bahasa yang benar sesuai dengan kaedah yang ada, merupakan kunci kelancaran dan kesempurnaan proses komunikasi.

Seseorang tidak dapat menerima dan menyampaikan pikiran, gagasan, perasaan, hasrat, dan kehendak secara efektif apabila orang tersebut tidak menguasai bahasa secara benar. Bahkan 


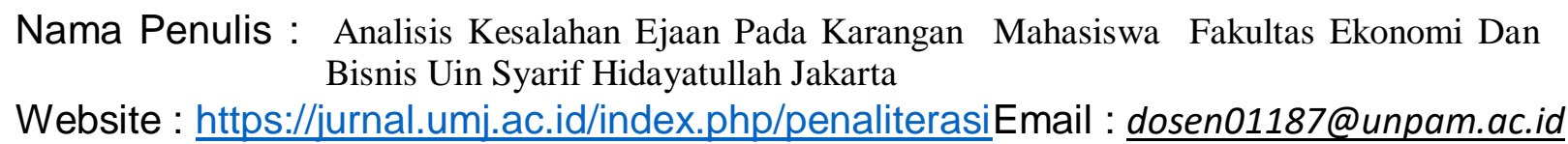

tingkat kualitas kegiatan intelektual seseorang akan sangat ditentukan oleh tingkat penguasaan bahasa yang dimilikinya. Selain untuk berkomunikasi secara langsung dengan menggunakan bahasa lisan, misalnya pidato atau ceramah, seseorang juga dapat berkomunikasi dengan bahasa tulis. Dalam komunikasi tulis, kita tidak begitu saja dapat melakukannya, tapi butuh ketrampilan untuk menuangkan pikiran, gagasan, perasaan, dan kehendak ke dalam bentuk tulisan.

Bahasa dalam karangan siswa selayaknya menggunakan bahasa baku sebagai sarananya, benar kaidahnya dan memenuhi cirri sebagai ragam standar. Namun, pada kenyataannya masih banyak ditemukan kesalahan dalam berbagai tataran bahasa, termasuk dalam penggunaan Ejaan khususnya dalam penggunaan pemakaian huruf kapital dan tanda baca. Ejaan sebagaimana telah dipahami bersama adalah keseluruhan peraturan bagaimana melambangkan bunyi-bunyi ujaran dan bagaimana menghubungkan antarhubungan antara lambing itu. Secara teknis yang dimaksud ejaan adalah penulisan huruf, penulisan kata, dan pemakaian tanda baca. Oleh karena itu penguasaan ejaan mutlak diperlukan bagi seseorang yang berkecimpung dalam kegiatan ilmiah. Atas dasar itu, dan melihat kenyataan bahwa masih banyak penyimpangan yang terjadi dalam proses berbahasa terutama bahasa tulis di kalangan Mahasiswa.

Secara umum tujuan penelitian ini untuk mengetahui Apa saja kesalahan penggunaan huruf dan tanda baca bahasa Indonesia yang terdapat dalam karangan mahasiswa Jurusan Manajemen Fakultas Ekonomi dan Bisnis Universitas Islam Negeri Syarif Hidayatullah Jakarta.

\section{A. Pengertian Kesalahan Bahasa}

Kesalahan bahasa adalah penyimpangan dari apa yang biasa berlaku dalam bahasa itu menurut criteria yang dianut oleh penutur aslinya. Supriyadi (1986:14) mengemukakan istilaah kesalahan bahasa sebagai bentuk penyimpangan wujud bahasa dari sistem atau kebiasaan berbahasa umumnya pada suatu bahasa sehingga menghambat kelancaran komunikasi berbahasa.

Penyimpangan yang dimaksud dapat terjadi pada pengucapan, cara penulisan, struktur kata, struktur kalimat, cara pengungkapan baik lisan maupun tulisan yang menyangkut dengan kebudayaan yang melatarbelakangi bahasa tersebut.

Kesalahan berbahasa (language eror) yang dilakukan oleh pembelajar dapat menunjukan pada tataran mana mereka banyak melakukan kesalahan. Kesalahan tersebut penting dalam beberapa hal. Pertama, kesalahan membantu guru untuk mengetahui sejauh mana arah kemajuan pembelajar.kedua, kesalahan menunjukan kepada peneliti tentang bagaimana siswa mempelajari dan menggunakan bahasa. Ketiga, kesalahan dapat membantu pembelajar itu sendiri untuk memperbaiki cara belajar, sehingga mereka bisa belajar dengan lebih baik lagi.(Corder, 1981:10).

Dari penjelasan ini ternyata kesalahan berbahasa bukanlah hal yang tidak selalu negatif. Bagi pengajar bahasa dan bagi peneliti bahasa, kesalahan dapat membantu langkah, prosedur, dan strategi dalam mengajarkan bahasa. Sedangkan bagi pembelajar sendiri, kesalahan dapat merupakan tolok ukur dan alat untuk mendororng agar bisa meningkatkan kompetensi bahasanya.

Brown (1994:206) mengemukakan bahwa, pada kenyataannya pembelajar bahasa selalu membuat kesalahan dan kesalahan tersebut dapat diobservasi, dianalisis, dan klasifikasi untuk mengetahui atau memperhatikan kesalahan pembelajar dalam suatu sistem pelaksanaan 
pembelajaran. (the fact that learners do make errors and that learners do make errors and that these errors can be observed, analyzed, and classified to reveral something of the system operating within the learner, led to a surge of study of learners errors, called error analysis).

Dari pernyataan ini dapat dijelaskan bahwa kesalahan bahasa dapat dijadikan sebagai obyek penelitian untuk mengetahui sejauh mana kemampan pembelajar dan keberhasilan dalam proses pembelajar bahasa.

\section{B. Hakikat Analisis Kesalahan Berbahasa}

Analisis kesalahan berbahasa berasumsi bahwa pembelajaran bahasa hendaknya lebih difokuskan pada frekuensi kesalahan berbahasa pembelajar. Penelusuran faktor penyebab dan jenis kesalahan yang dilakukan oleh pembelajar jauh lebih penting karena dapat dipergunakan sebagia dasar untuk memperbaiki kesalahan pembelajaran dan kesalahan berbahasa pembelajar. Analisis kesalahan lebih menekankan pada aspek kreatifitas pembelajar bahasa dan menempatkan mereka sebagai titik pusat pembelajaran bahasa, karena mereka yang banyak melakukan kegiatan berbahasa. Dari kegiatan berbahasa ini munculah berbagai kesalahan dan persoalan yang dilakukan oleh mereka, sehingga muncul inspirasi para pakar bahasa untuk meneliti kesalahan dan menganalisis apa faktor penyebab kesalahan berbahasa.

Para ahli ilmu bahasa banyak memberikan definisi atau penjelasan tentang istilah analisis kesalahan berbahasa. Untuk mengetahui istilah analisis keslahan behasa, berikut penjelasan para ahli ilmu bahasa tersebut. James (1998:137) menyatakan bahwa, analisis kesalahan bahasa merupakan proses penentuan munculnya sifat, sebab dan akibat ketidaksuksesan pembelajar bahasa (ereor analysis is the process of determining the incidence, nature causes and consequences of unsuccessful language.) Selanjutnya Richards (1974:173) menyatakan bahwa apa yang telah muncul diketahui sebagai analisis kesalahan harus dilakukan penyelidikan bahasa pembelajar bahasa kedua (what has come to be known as error analysis has to do with the invertigation of the language of second language learners).

Analisis keslahan bahasa merupakan pengkajian tentang ketidaktahuan linguistic yang dilakukan oleh orang atau pembelajar bahasa sasaran. Hasil penyelidikan tersebut dapat dijadikan pertimbangan dan masukan kepada pembelajar tentang jenis kesalahan yang telah mereka lakukan sehingga pembelajar tersebut dapat mengatasi dan memperbaiki sendiri kesalahannya. Dalam pernyataan James menggunakan istilah ketidaktahuan linguistic (linguistic ignorance) dan apa yang orang tidak ketahui (what people do not know), hal ini berarti keslahan itu muncul karena seseorang tidak mengetahui atau belum menguasai linguistic bahasa sumber, sehingga mereka menggunakan sesuatu yang tidak diketahui tersebut yang mengakibatkan kesalahan dan pemakaian bahasa atau kesalahan performansi.

\section{Fungsi Analisis Kesalahan Bahasa}

Melaksanakan penyelidikan atau analisis terhadap kesalahan bahasa tentu ada fungsi dan manfaatnya dalam pembelajaran bahasa, yaitu untuk memberikan umpan balik yang berharga bagi pengajar dan pembelajar dalam proses belajar mengajar, baik dari aspek teoretis maupun aspek praktis. Corder menjelaskan dua fungsi tersebut yakni, aspek teoretis analisis kesalahan bahasa adalah bagian dari metodologi penyelidikan proses pembelajaran bahasa, dan aspek praktis analisis kesalahan berbahasa adalalah berfungsi sebagai panduan dalam tindakan remedial. (Corder, 1981:45) 
Nama Penulis : Analisis Kesalahan Ejaan Pada Karangan Mahasiswa Fakultas Ekonomi Dan Bisnis Uin Syarif Hidayatullah Jakarta

Website : https://jurnal.umj.ac.id/index.php/penaliterasiEmail : dosen01187@unpam.ac.id

Fungsi aspek teoretis analisis

kesalahan bahasa yang merupakan bagian dari metodologi penyelidikan proses pembelajaran bahasa agar supaya menemukan sifat proses pembelajaran tersebut secara psikologis. Dalam proses ini kita harus mempunyai craa untuk mengabarkan pengetahuan (competence) bahasa sasaran pembelajar bahasa, agar supaya pembelajar dapat dihubungkan pengetahuannya atau materi yang telah mereka terima dengan pembelajaran.

Sedangkan aspek praktis analisis kesalahan berbahasa adalah berfungsi sebagai panduan dalam tindakan perbaikan kembali (remedial) yang harus dilakukan untuk memperbaiki kesalahan berbahasa dan untuk mendeteksi agar ada kecocokan atau ketepatan di dalam memperbaiki kesalahan tersebut. Tindakan ini sangat bermanfaat bagi pengajar maupun pembelajar itu sendiri dalam proses pembelajaran bahasa sasaran.

Selanjutnya analisis kesalahan berbahasa mempunyai berbagai tujuan dan manfaat, baik yang bersifat linguistis, praktis, politis, sosiokultural, dan sebagainya, yang bisa dipergunakan dalam proses pembelajaran bahasa. Hal ini terlihat seperti yang dikemukakan oleh Hendricson dan Corder yang dikutip oleh Nababan (1994:92), mereka mengatakan bahwa:

Analisis kesalahan bahasa itu berguna untuk mengetahui beberapa hal mengenai kesalahan yang dibuat oleh pembelajar bahasa sasaran yaitu:

1. Keslahan berguna sebagai tanda bahwa pembelajar bahasa sasaran memang sungguh belajar

2. Kesalahn merupakan indicator bahwa ada kemajuan

3. Kesalahan memberikan umpan balik tentang efektivitas materi ajar dan metode penyajian oleh pengajar

4. Kesalahan menunjukan bagian mana dari suatu silabus bahasa yang belum dipelajari dengan sempurna,

5. Kesalahan yang banyak dibuat dapat menjadi bahan untuk penulisan latihan perbaikan.

Di sisni terlihat sekali kegunaan analisis kesalahan dari berbagai aspek dalam proses pembelajaran,seperti sebagai tanda kesungguhan dan kemajuan pemeblaajar, keefektivitasan meteri ajar dan metode yang digunakan dalam pembelajaran, mengetahui ketercapaian tujuan yang telah ditetapkan dalam kurikulum, dan acuan terhadap perbaikan materi atau remedial yang diajarkan.

\section{Pengertian Ejaan}

Pemakaian ejaan yang benar merupakan salah satu faktor yang menentukan kesempurnaan bahasa tulisan. Ejaan merupakan seperangkat kaidah yang mengatur cara melambangkan bunyi ujaran, cara memisahkan dan menggambungkan lambang-lambang itu dalam suatu bahasa. Sejalan dengan pengertian di atas, Keraf (1997:3) menyatakan bahwa ejaan adalah keseluruhan dari peraturan bagaimana menggambarkan lambang-lambang bunyi ujaran dan bagaimana interaksi antara lambang-lambang itu (pemisahannya, penggabungannya) dalam suatu bahasa.

Menurut Kamus Besar Bahasa Indonesia (KBBI) dalam Sriyanto (2016:5) ejaan adalah kaidah cara menggambarkan bunyi-bunyi (kata, kalimat dan sebagainya) dalam tulisan (huruf-huruf) serta penggunaan tanda baca.

Menurut Badudu (1988:7) lazimnya ejaan memiliki tiga aspek: 
1. Aspek fonologis yang menyangkut penggambaran fonem dengan huruf dan penyusunan maksud

2. Aspek morfologi yang menyangkut penggambaran satuan-satuan morfemis

3. Aspek sintaksis yang menyangkut penanda ujaran tanda baca.

\section{E. Penerapan Ejaan}

\section{Huruf}

Huruf kapital digunakan sebagai:

a. Huruf pertama awal kalimat

Semoga Allah memberkati usaha

Saudara

b. Huruf pertama petikan langsung

Pak Haji itu berkata, "Puasa itu menahan diri dari hawa nafsu"

c. Huruf pertama dalam ungkapan yang berhubungan dengan hal-hal keagamaan, kitab suci, nama Tuhan termasuk kata gantinya

Al-Quran adalah pembeda antara yang hak dan yang batil

d. Huruf pertama gelar kehormatan atau keturunan, keagamaan yang diikuti nama orang

Salah satu nama calon anggota legislative dari daerah saya adalah Raden Haji Muhammad Badruddin, S.H.

e. Huruf pertama nama jabatan dan pangkat yang diikuti nama orang Gubernur yang terpilih pada pilkada yang lalu bernama Letnan Jendral Suryanto, S.H.

f. Huruf pertama nama orang

Anak saya yang pertama bernama Zainuddin

g. Huruf pertama nama bangsa, suku, bahasa

Bahasa Melayu merupakan cikal bakal bahasa Indonesia

h. Huruf pertama nama tahun, bulan, hari, hari raya, dan peristiwa sejarah
Salah satu perang yang banyak makan korban di zaman Rasulullah adalah Perang Badar

i. Huruf pertama nama khas geografi Ibukota Kalimantan Barat adalah Pontianak

j. Huruf pertama nama resmi badan, lembaga, pemerintahan, ketatanegaraan, serta nama dokumen resmi

Kasus korupsi di Departemen Kelautan dan Perikanan sangat memprihatinkan

k. Huruf pertama semua kata dalam nama buku, majalah, surat kabar, dan judul karangan, kecuali partikel seperti di, ke, dari, untuk, dan yang tidak terletak pada posisi awal

Artikel berjudul "Pernak-Pernik Kehidupan" ditulis dalam Harian Panji Gunung Mas

1. Huruf pertama dalam singkatan nama, gelar, dan sapaan.

Dosen mata kulian Dasar-dasar 'Ulumul Hadits diampu oleh Dr. H. M. Miftahul Ulum, M.A.

m. Huruf pertama hubungan kekerabatan seperti: bapak, ibu, saudara, kakak, adik, dan paman yang dipakai sebagai kata ganti atau sapaan

Bila tidak berkeberatan, Bapak kami undang untuk datang ke tempat kami segera

\section{Tanda Baca}

Ramlan dan Mahmudah (2010:43) menjelaskan bahwa salah satu yang sering diabaikan orang dalam menulis adalah penggunaan tanda baca (pungtuasi). Padahal, tanda baca dapat membantu seseorang dalam memahami isi bacaan." Bayangkanlah jika sebuah teks/wacana tidak menggunakan tanda baca. Sedah barang tentu, bacaan tersebut tidak dapat dipahami.

a. Titik

Titik digunakan:

1) Pada akhir kalimat 
Nama Penulis : Analisis Kesalahan Ejaan Pada Karangan Mahasiswa Fakultas Ekonomi Dan Bisnis Uin Syarif Hidayatullah Jakarta

Website : https://jurnal.umj.ac.id/index.php/penaliterasiEmail : dosen01187@unpam.ac.id

Semoga Allah Swt.

mengabulkan doa kita

2) Pada singkatan nama orang Imam mesjid di kotaku bernama A. Syafei

3) Pada singkatan gelar, pangkat, jabatan, dan sapaan.

Sejak Prof. Dr. Ir. H. Sastrowardoyo, S.H. menjadi bupati, pembangunan di daerah saya sangat maju.

4) Pada singkatan kata atau ungkapan yang sudah sangat umum

Sdr. Saudara Yth. Yang terhormat Saw. Sallallahu 'alaihi wa sallam

5) Untuk memisahkan angka jam, menit, dan detik

Walimah nikah it dimulai pada pukul 07.30.

b. Koma

Koma digunakan pada:

1) Diantara unsur-unsur dalam suatu pemerian

Barang yang kan saya beli di pasar Hrco Glodok adalah hardisc, CD, printer, laptop, dan sebagainya.

2) Untuk memisahkan bagian kalimat setara yang menggunakan tetapi dan melainkan.

Rumah yang akan dijual bagus sekali, tetapi harganya murah

3) Untuk memisahkan anak kalimat dengan induk kaliamat jika anak kalimat mendahului induknya.

Jika mampu, orang Islam wajib melaksanakan ibadah haji

Bandingkan dengan:
Orang Islam wajib

melaksanakan ibadah haji jika mampu

4) Di belakang kata atau ungkapan penghubung antarkalimat yang terdapat dalam posisi awal.

Jika demikian, kami tidak akan meluluskan permintaan Anda

5) Di belakang kata seru yang terdapat pada posisi awal.

Mari, Nak!

6) Untuk memisahkan petikan langsung dari bagian lain pada suatu kalimat.

Amir bertanya kepadaku, "Kapan gaji PNS akan dinaikkan?"

7) Diantara unsur-unsur alamat yang di tulis berurutan

Jika Anda ingin berkirim surat, alamatkan ke:

Jln. Kertamukti, Gg. H. Nipan

No. 20 A, RT 001/08, Desa

Pisangan, Kecamatan Ciputat, Kode Pos 15419 Kabupaten Tangerang.

8) Untuk memisahkan bagian nama yang dibalik susunannya dalam daftar pustaka.

Saenong, Ilham B. 2002. Hermeneutika Pembebasan: Metodologi Tafsir al-Quran menurut Hasan Hanafi. Jakarta: Teraju

9) Untuk memisahkan bagainbagian dalam catatan kaki Ibnu Hajar al-Asqalani, Tahzib al-Tahzib, (Beirut: Daral Fikr, 1404), hlm. 10.

10) Di antara nama orang dan gelar akademik yang mengikutinya untuk membedakannya dari singkatan nama keluarga atau marga. 
Siding perkara pencemaran nama baik itu dipimpin oleh Hakim Krtua Malin Sitohang, S.H., M.Si. (S.H. Sarjana Hukum, M.Si. Magister Sains)

Bandingkan:

Kepala desa terpilih pada pilkades tahun ini adalah Suroto S.H. (S.H. Sastro Hudooyo)

11) Di muka angka persepuluhan dan di antara rupiah dan sen dalam bilangan

Panjang jalan Tanjung PandanSijuk adalah 24,6 km.

12) Untuk mengapit keterangan tambahan dan keterangan aposisi

Dosen kami, Pak Mustofa, sering berceramah di televisi

c. Titik Koma (;)

Titik koma digunakan untuk:

Untuk memisahkan bagian-bagian kalimat yang sejenis dan setara

Contoh:

Amir sedang menulis surat; kakaknya sedang mengaji; ibu sedang melaksanakan shalat Isya.

d. Titik dua (:)

Titik dua digunakan untuk:

1) Pada akhir suatu pernyataan lengkap bila diikuti rangkaian atau pemerian, misalnya:

Ada sepuluh macam barang elektronik yang akan saya beli, yaitu: pesawat, televise, kipas angin, kulkas, blender, dan sebagainya.

2) Sesudah kata atau ungkapan yang memenlukan pemerian.

Dengan ini kami mengharapkan kehadiran Bapak/Ibu/Sdr. pada Puncak Peringatan Maulid Nabi Muhammad Saw.

hari, tanggal : $\quad$ 19.30-

selesai pukul : $\quad$ Tablig

Akbar bersama Ustadz Arifin

Ilham

tempat : Mesjid

Darussalam Kel. Cijantung Jakarta Timur

3) Dalam teks drama, sesudah kata yang menunjukkan pelaku percakapan.

Pak Haji : (sambil membawa tasbih) Kamu sudah melaksanakan shalat magrib Nur?

Nur : Belum pak haji, soalnya biasa pak lagi halangan.

4) Di antara jilid atau nomor halaman, di antara bab dan ayat dalam kitab suci atau di antara judul dan anak judul suatu karangan, nama kota dan penerbit buku baik dalam catatan kaki/daftar pustaka.

Fuad Said, Hakikat Tarikat Naqsabandiyah, (Jakarta: Husna Zikra, 1999), h. 245

e. Tanda hubung (-)

Tanda hubung (-) digunakan untuk:

1) Menyambung suku-suku kata yang terpisah karena pergantian baris.

Semua umat Islam pada Hakikatnya cinta perdamaian kare-

na sejak munculnya Islam, Rasulullah telah mengajarkan hal itu.

2) Menyambung awalan dengan bagian kata di belakangnya.

Kate beriman terdiri dari morfem bebas iman dan morfem terikat ber-

3) Menyambung unsur-unsur kata ulang.

Sambil beramah-ramah, para undangan dipersilahkan untuk 
Nama Penulis : Analisis Kesalahan Ejaan Pada Karangan Mahasiswa Fakultas Ekonomi Dan Bisnis Uin Syarif Hidayatullah Jakarta

Website : https://jurnal.umj.ac.id/index.php/penaliterasiEmail : dosen01187@unpam.ac.id

bersantai sambil mendengarkan lagu-lagu kasidahan.

4) Menyambung huruf kata yang dieja

Kata iman terdiri dari huruf i$\mathrm{m}-\mathrm{a}-\mathrm{n}$

5) Untuk memperjelas hubungan bagian-bagian ungkapan dan penghilangan bagian kelompok kata.

Menurut teori Darwin, semua makhluk hidup itu ber-evolusi

Ayah saya ikut ber-revolusi pada tahun 1945

6) Merangkai se- dengan bagiambagian berikutnya yang dimulai dengan huruf kapital ke dengan angka, angka dengan -an, singkatan huruf kapital dengan imbuhan atau kata atau sebaliknya.

Sampai tahun 1990-an, Indonesia belum terlepas dari krisis ekonomi.

7) Merangkaikan unsur bahasa indonesia dengan unsur asing.

Pemain handalan bulu tangkis Cina men-smash bola sehingga lawan tidak berkutik

f. Tanda pisah (--)

Tanda pisah dipakai untuk:

1) Membatasi penyisipan kata atau kalimat yang memberi penjelasan.

Masalah sengketa tanah itu saya yakin-insya Allah akan selesai, namun mungkin dalam waktu yang relative lama.

2) Menegaskan adanya aposisi.

Pak Badrun -salah seorang calon lurah di kampong sayalangsung jatuh sakit setelah mengetahui dirinya kalah dalam pemilihan.
3) Di antara dua bilangan atau tanggal yang berarti sampai

Acara pertemuan antara perwakilan korban lumpur Lapindo dengan perwakilan pemerintah berlangsung dari pukul 19.00-22.30 Wiba.

g. Tanda Elipsis (...) digunakan untuk:

1) Menggambarkan kalimat yang terputus-putus

Amir berkata, "Kalau begitu ... saya tidak tahu ... bukan saya!"

2) Menunjukkan bahwa dalam suatu petikan ada bagian yang dihilangkan.

Dalam bukunya, Nana Sudjana dan Daeng Arifin (1988: 57) menyatakan, "Mengerjakan (doing) merupakan perwujudan sikap dan tingkah laku manusis (aspek psikomotorik). Aspek ini ..."

3) Meminta kepada pembaca mengisi sendiri kelanjutan dari sebuah kalimat.

Islam adalah ... yang universal.

h. Tanda tanya (?) digunakan untuk:

1) Akhir kalimat tanya

Apa yang kamu ketahui tentang zakat?

2) Menyatakan bagian kalimat yang si sangsikan atau yang kurang dapat dibuktikan kebenarannya.

Dalam keterangannya kepada warga, pria asing itu menyatakan bahwa dia adalah salah seorang anak kandung Pak Bendung (?). pak Bendung adalah penduduk asli yang sudah lama meninggalkan desa kami. Masalahnya, seingat saya, Pak Bendung tidak mempunyai anak laki-laki. 
i. Tanda seru (!) digunakan untuk:

Sesudah ungkapan atau pernyataan yang berupa seruan atau perintah Masya Allah, alangkah pandainya dia!

j. Tanda $\operatorname{kurung}((\ldots))$ digunakan untuk:

1) Mengapit keterangan atau penjelasan

Petunjuk pelaksana (juklak) projek itu sudah ditandatangani oleh gubernur.

2) Mengapit penjelasan yang bukan bagian yang integral dari pokokpembicaraan.

Data yang penulis dapatkan dari observasi lapangan (lihat tabel XI) membuktikan bahwa angka kelulusan SMA Mayangsari relative rendah.

k. Tanda garis miring (/) digunakan untuk:

1) Dalam penomoran kode surat dan nomor pada alamat

Alamatnya di jalan Patimura Blok F-16/12 Gandul Cinere.

2) Pengganti kata atau, per, atau tiap

Harga kertas A-1 sekarang Rp25.000,00/rim

1. Tanda petik ganda (“...”) digunakan untuk:

1) Mengapit petikan langsung berasal dari pembicaraan naskah atau bahan tertulis lain.

Ayah berkata, "Salatlah sebelum habis waktunya!"

2) Mengapit judul syair, karangan dan bab buku apabila sipakai dalam kalimat, dll.

3) Mengikuti tanda baca yang mengakhiri petikan langsung

4) Mengapit istilah ilmiah yang kuurang dikenal atau kata yang memiliki arti khusus
5) Sebagai penutup kalimat atau bagian kalimat yang ditempatkan di belakang tanda petik yang mengapit kata atau ungkapan yang dipakai dengan arti khusus

m. Petik tunggal ('...') digunakan untuk:

1) Mengapit petikan dalam petikan, misalnya:;

Ayah bertanya, "kamu dengar bunyi 'Allahu akbar-Allahu akbar' tadi?

2) Mengapit makna, terjemahan, atua penjelasan kata atau ungkapan asing, misalnya:

Jika mengacu kepada altarbiyah-al-islamiyah 'pendidikan Islam' berarti kita mengacu kepada pendidikan berdasarkan Quran dan Sunah.

\section{METODE PENELITIAN}

M

etode penelitian yang digunakan dalam penelitian ini adalah deskriptif analisis, yang mana dengan tujuan penelitian yakni untuk memperoleh data atas suatu permasalahan yang sedang diteliti. Metode ini dimulai dengan mempersiapkan instrument, mengumpulkan data, informasi dan fakta-fakta yang tersedia di lapangan yang kemudian dipaparkan secara jelas dan sistematis sehingga mampu menguraikan permasalhan yang dijelaskan sebelumnya.

Populasi dalam penelitian ini adalah seluruh mahasiswa semester II Juruasan Manajemen Fakultas Ekonomi dan Bisnis Universitas Islam Negeri Syarif Hidayatullah Jakarta. Sampel penelitian ini penulis mengambil sampel sebanyak 30 orang mahasiswa semester II Jurusan Manajemen Fakultas Ekonomi dan Bisnis Universitas Islam Negeri Syarif 
Nama Penulis : Analisis Kesalahan Ejaan Pada Karangan Mahasiswa Fakultas Ekonomi Dan Bisnis Uin Syarif Hidayatullah Jakarta

Website : https://jurnal.umj.ac.id/index.php/penaliterasiEmail : dosen01187@unpam.ac.id

HIdayatullah Jakarta dengan menggunakan metode Random Sampling.

Teknik pengumpulan data yang digunakan dalam penelitian ini di antaranya adalah sebagai berikut:

a. Teknik Tes

Teknik ini digunakan untuk mendapatkan data mengenai kesalahan penggunaan huruf dan tanda baca dalam karangan persuasi mahasiswa Jurusan Manajemen Fakultas Ekonomi dan Bisnis Universitas Islam Negeri Syarif Hidayatullah Jakarta.

b. Studi pustaka

Teknik ini dilakukan dengan cara membaca literature yang relevan dengan penelitian sehingga dapat dijadikan sebagai landasan teori.

Teknik analisis data yang digunakan dalam penelitian ini menggunakan model analisis mengalir, yang meliputi tiga komponen, yaitu 1) reduksi data; 2) penyajian data; dan 3) penarikan simpulan.

Prosedur penelitian yang dilakukan peneliti terdiri dari beberapa tahap sebagai berikut.

1. Pengumpulan data

Pada tahap ini peneliti mengumpulkan data berupa kutipankutipan yang menunjukkan analisis keslahan penggunaan huruf dan tanda baca mahasiswa Jurusan Manajemen Fakultas Ekonomi dan Bisnis Universitas Islam Negeri Syarif Hidayatullah Jakarta.

2. Penyeleksian data

Data-data yang telah dikumpulkan, kemudian diseleksi serta dipilah-pilah mana saja yang akan dianalisis.

3. Menganalisis data yang telah diseleksi.

4. Membuat laporan penelitian.

Laporan penelitian merupakan tahap akhir dari serangkaian proses. merupakan tahap penyampaian data-data yang telah dianalisis, dirumuskan, dan ditarik kesimpulan.
Instrument yang digunakan dalam penelitian ini adalah tes tertulis. Tes tertulis diberikan dalam bentuk pemberian tugas yakni membubuhkan huruf capital dan tanda baca yang tepat pada paragraf persuasi.

Peneliti dalam melakukan analisis dibantu dengan tabel analisis data berikut, untuk mempermudah peneliti melakukan analisis kesalahan yang dilakukan oleh siswa.

Tabel 1

Kesalahan Penggunaan Huruf

\begin{tabular}{|c|c|c|c|}
\hline No & Kalimat & $\begin{array}{c}\text { Bentuk } \\
\text { Kesalahan }\end{array}$ & Perbaikan \\
\hline & & & \\
\hline & & & \\
\hline
\end{tabular}

Tabel 2

Kesalahan penggunaan tanda baca

\begin{tabular}{|c|c|c|c|}
\hline No & Kalimat & $\begin{array}{c}\text { Bentuk } \\
\text { Kesalahan }\end{array}$ & Perbaikan \\
\hline & & & \\
\hline & & & \\
\hline
\end{tabular}

Tabel 3

Tabulasi Kategori Kesalahan

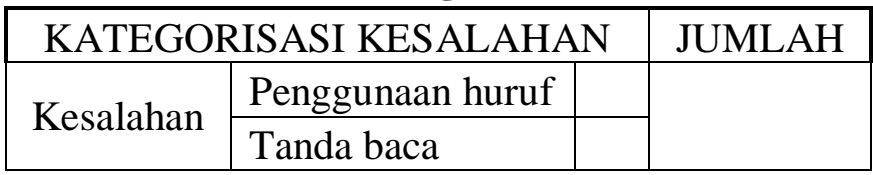

\section{HASIL DAN PEMBAHASAN}

\section{A. Gambaran Umum Hasil Penelitian}

Mahasiswa Jurusan Manajemen Fakultas Ekonomi dan Bisnis Universitas Islam Negeri Syarif Hidayatullah Jakarta merupakan pembelajar yang berasal dari berbagai kalangan. Mayoritas mahasiswa jurusan Manajemen merupakan mahasiswa yang tidak memperdulikan penulisan dari bahasa Indonesia, mereka hanya okus dalam hal-hal yang menyangkut ekonomi dan bidang studinya. Pendidikan yang mereka dapatkan dari sekolah-sekolah asal mereka tidak begitu memperhatikan penggunaan penulisan bahasa Indonesia. Keadaan tersebut nampak dalam hasil 
penelitian ini, banyak dari mereka yang masih membawa "Budaya" bahasa mereka yang tidak memperdulikan penulisan ejaan yang mereka buat.

Ketidaktelitian mahasiswa dalam menulis dalam menggunaakan ejaan seringkali terjadi. Adapun kesalahan yang dilakukan oleh mahasiswa pada penelitian ini merupakan kesalahan murni yang mereka lakukan karena kekeliruan dalam aplikasi penggunaan kaidah penulisan ejaan dalam bahasa Indonesia.

\section{B. Deskripsi Data}

Data yang didapatkan dari 35 ktulisan paragraph persuasi siswa yang kemudian direduksi menjadi 23 tulisan mahasiswa yang terdapat kesalahan. Kesalahan yang ditemukan terbagi menjadi 2 jenis kesalahan yaitu kesalahan penggunaan huruf dan penggunaan tanda baca Berikut disajikan dalam tabel data kesalahan:

Tabel 1

Kesalahan Penggunaan Huruf

\begin{tabular}{|l|l|l|l|}
\hline No & \multicolumn{1}{|c|}{ Kalimat } & $\begin{array}{c}\text { Bentuk } \\
\text { Kesalahan }\end{array}$ & $\begin{array}{c}\text { Perbaika } \\
\text { n }\end{array}$ \\
\hline 1. & $\begin{array}{l}\text { Banyak Faktor } \\
\text { pendukung } \\
\text { terjadinya } \\
\text { kemacetan }\end{array}$ & $\begin{array}{l}\text { Banyak } \\
\text { Faktor }\end{array}$ & $\begin{array}{l}\text { Banyak } \\
\text { faktor }\end{array}$ \\
\hline 2. & $\begin{array}{l}\text { Untuk } \\
\text { menghindari } \\
\text { kita dari } \\
\text { Jeratan } \\
\text { narkoba }\end{array}$ & Jeratan & jeratan \\
\hline 3. & $\begin{array}{l}\text { Pertama, } \\
\text { tingkatkanlah } \\
\text { keimanan kita } \\
\text { kepada Allah } \\
\text { SWT dengan } \\
\text { memperbanya } \\
\text { k ibadah }\end{array}$ & Sllah & $\begin{array}{l}\text { Allah } \\
\text { Swt }\end{array}$ \\
\hline 4. & $\begin{array}{l}\text { Yang lelah } \\
\text { menjalani } \\
\text { keseharian } \\
\text { mereka di }\end{array}$ & jakarta & Jakarta \\
\hline
\end{tabular}

\begin{tabular}{|c|c|c|c|}
\hline & $\begin{array}{l}\text { Ibukota } \\
\text { jakarta yang } \\
\text { penuh dengan } \\
\text { permasalahan }\end{array}$ & & \\
\hline 5. & $\begin{array}{l}\text { Satu Persatu } \\
\text { Pekerja mulai } \\
\text { berdatangan } \\
\text { untuk } \\
\text { menyelesaikan } \\
\text { Pekerjaannya. }\end{array}$ & $\begin{array}{l}\text { - } \text { Satu } \\
\text { Persatu } \\
\text { Pekerja } \\
\text { - Pekerjaa } \\
\text { nnya }\end{array}$ & $\begin{array}{l}\text { - Satu } \\
\text { persatu } \\
\text { pekerja } \\
\text { - pekerja } \\
\text { annya }\end{array}$ \\
\hline 6. & $\begin{array}{l}\text { Faktanya, } \\
\text { manusia } \\
\text { diciptakan leh } \\
\text { Allah s.w.t } \\
\text { untuk menjadi } \\
\text { khalifah } \\
\text { diBumi }\end{array}$ & Di Bumi & di bumi \\
\hline 7. & $\begin{array}{l}\text { mari buang } \\
\text { sampah pada } \\
\text { tempatnya dan } \\
\text { selamatkan } \\
\text { Bumi! }\end{array}$ & $\begin{array}{ll}- & \text { mari } \\
\text { - } & \text { Bumi }\end{array}$ & $\begin{array}{ll}\text { - } & \text { Mari } \\
\text { - } & \text { bumi }\end{array}$ \\
\hline 8. & $\begin{array}{l}\text { Penyalahguna } \\
\text { an terhadap } \\
\text { Narkba sangat } \\
\text { dipengaruhi } \\
\text { leh pergaulan } \\
\text { bebas remaja } \\
\text { sekarang }\end{array}$ & Narkoba & narkoba \\
\hline 9. & $\begin{array}{l}\text { Lantainya } \\
\text { terbuat dari } \\
\text { kayu, } \\
\text { Temboknya } \\
\text { dilukis seperti } \\
\text { rumah-rumah } \\
\text { di London }\end{array}$ & $\begin{array}{l}\text { Tembokny } \\
\text { a }\end{array}$ & $\begin{array}{l}\text { tembokn } \\
\text { ya }\end{array}$ \\
\hline 10. & $\begin{array}{l}\text { Akhir-akhir } \\
\text { ini kita sering } \\
\text { melihat berita- } \\
\text { berita di } \\
\text { Televisi } \\
\text { Tentang banjir } \\
\text { yang melamda } \\
\text { Ibukota } \\
\text { jakarta. }\end{array}$ & $\begin{array}{ll}- & \text { Televis } \\
& \mathrm{i} \\
- & \text { Tentan } \\
& \mathrm{g} \\
- & \text { jakarta }\end{array}$ & $\begin{array}{ll}- & \text { televi } \\
& \text { si } \\
- & \text { tentan } \\
& \text { g } \\
- & \text { Jakart } \\
& \text { a }\end{array}$ \\
\hline 11. & $\begin{array}{l}\text { Perkembangan } \\
\text { Ekonomi yang } \\
\text { pesat harus di } \\
\text { Imbangi } \\
\text { dengan }\end{array}$ & $\begin{array}{ll}- & \text { Ekono } \\
& \text { mi } \\
- & \text { Imbang } \\
& \mathrm{i} \\
- & \text { Transp }\end{array}$ & $\begin{array}{ll}\text { - } & \text { ekono } \\
& \text { mi } \\
\text { - } & \text { imban } \\
& \text { gi } \\
\text { - } & \text { Trans }\end{array}$ \\
\hline
\end{tabular}

102 |P ena Literasi 
Nama Penulis : Analisis Kesalahan Ejaan Pada Karangan Mahasiswa Fakultas Ekonomi Dan Bisnis Uin Syarif Hidayatullah Jakarta

Website : https://jurnal.umj.ac.id/index.php/penaliterasiEmail : dosen01187@unpam.ac.id

\begin{tabular}{|c|c|c|c|}
\hline & $\begin{array}{l}\text { Transportasi } \\
\text { yang memadai }\end{array}$ & ortasi & $\begin{array}{l}\text { portas } \\
\text { i }\end{array}$ \\
\hline 12. & $\begin{array}{l}\text { Kurang } \\
\text { berkembangny } \\
\text { a Perdagangan } \\
\text { di Indonesia } \\
\text { agaknya } \\
\text { dipengaruhi } \\
\text { kurangnya } \\
\text { infrastruktur } \\
\text { yang } \\
\text { mendukung. }\end{array}$ & $\begin{array}{l}\text { Perdagang } \\
\text { an }\end{array}$ & $\begin{array}{l}\text { perdagan } \\
\text { gan }\end{array}$ \\
\hline 13. & $\begin{array}{l}\text { Sehingga } \\
\text { jepang tidak } \\
\text { perlu } \\
\text { melakukan } \\
\text { ekspor }\end{array}$ & jepang & Jepang \\
\hline 14. & \begin{tabular}{l}
\multicolumn{2}{l}{ Ruangan } \\
Berukuran 100 \\
x 90 m ini \\
sungguh \\
nyaman \\
ditempati \\
Sebuah kursi \\
kayu berwarna \\
coklat dengan \\
meja Kayu \\
berada di \\
tengah \\
ruangan.
\end{tabular} & $\begin{array}{l}\text { - Berukur } \\
\text { an } \\
\text { - Sebuah } \\
\text { - Kayu }\end{array}$ & $\begin{array}{ll}\text { - } & \text { beruk } \\
& \text { uran } \\
\text { - } & \text { sebuh } \\
\text { - } & \text { kayu }\end{array}$ \\
\hline 15 & $\begin{array}{l}\text { Disorotinya } \\
\text { oleh terangnya } \\
\text { lampu jalan, } \\
\text { pengendara } \\
\text { disuguhi para } \\
\text { pengamen } \\
\text { yang dari tadi } \\
\text { menyanyikan } \\
\text { Lagu tanpa } \\
\text { lelah, Tidak } \\
\text { jelas penyebab } \\
\text { kemacetan ini } \\
\text { yang membuat } \\
\text { antrean } \\
\text { kendaraan } \\
\text { begitu } \\
\text { panjang. }\end{array}$ & $\begin{array}{l}\text { Tidak } \\
\text { jelas }\end{array}$ & $\begin{array}{l}\text { tidak } \\
\text { jelas }\end{array}$ \\
\hline
\end{tabular}

\begin{tabular}{|l|l|l|l|}
\hline 16. & $\begin{array}{l}\text { Salah satu } \\
\text { alasan indonesia } \\
\text { terjadinya } \\
\text { banjir adalah } \\
\text { sampah di } \\
\text { indonesia } \\
\text { yang menutup } \\
\text { jalur air hujan } \\
\text { yang } \\
\text { mengakibatka } \\
\text { n air tersendat } \\
\text { dan naik ke } \\
\text { permukaan. }\end{array}$ & a \\
\hline 17. & $\begin{array}{l}\text { Kemacetan } \\
\text { nampaknya } \\
\text { sudah menjadi } \\
\text { hal yang biasa } \\
\text { terlihat di } \\
\text { jalanan } \\
\text { Ibukota } \\
\text { jakarta. }\end{array}$ & jakarta & Jakarta \\
\hline
\end{tabular}

Tabel 2

Kesalahan penggunaan tanda baca

\begin{tabular}{|l|l|l|l|}
\hline No & \multicolumn{1}{|c|}{ Kalimat } & $\begin{array}{c}\text { Bentuk } \\
\text { kesalaha } \\
\mathrm{n}\end{array}$ & $\begin{array}{l}\text { Perbaik } \\
\text { an }\end{array}$ \\
\hline 1 & $\begin{array}{l}\text { Agar sistem } \\
\text { pencernaan } \\
\text { lancar danmudah } \\
\text { untuk membuang } \\
\text { air besar }\end{array}$ & $\begin{array}{l}\text { Air besar } \\
\text {. }\end{array}$ & $\begin{array}{l}\text { Air } \\
\text { besar. }\end{array}$ \\
\hline 2 & $\begin{array}{l}\text { Tapi jika sudah } \\
\text { menggunakannya } \\
\text { bagaimana } \\
\text { bentuk badanmu? }\end{array}$ & $\begin{array}{l}\text { Menggu } \\
\text { nakanny } \\
\text { a }\end{array}$ & $\begin{array}{l}\text { Mengg } \\
\text { unakan } \\
\text { nya, }\end{array}$ \\
\hline 3 & $\begin{array}{l}\text { Di daerah lainpun } \\
\text { sekarang sudah } \\
\text { terjamah oleh } \\
\text { kemacetan },\end{array}$ & $\begin{array}{l}\text { Kemacet } \\
\text { an, }\end{array}$ & $\begin{array}{l}\text { Kemac } \\
\text { etan, }\end{array}$ \\
\hline 4 & $\begin{array}{l}\text { Ketika masih } \\
\text { banyak partai } \\
\text { politik yang } \\
\text { hanya } \\
\text { berorientasi pada } \\
\text { uang dan } \\
\text { kekayaan, Ada } \\
\text { sebuah organisasi }\end{array}$ & $\begin{array}{l}\text { uang dan } \\
\text { kekayaan } \\
\text { Ada }\end{array}$ & $\begin{array}{l}\text { uang } \\
\text { dan } \\
\text { kekaya } \\
\text { an, ada }\end{array}$ \\
\hline
\end{tabular}




\begin{tabular}{|c|c|c|c|}
\hline & $\begin{array}{l}\text { baru bentukan } \\
\text { pak Hari } \\
\text { Tanesudibjo. }\end{array}$ & & \\
\hline 5 & $\begin{array}{l}\text { Faktanya, } \\
\text { manusia } \\
\text { diciptakan leh } \\
\text { Allah s.w.t untuk } \\
\text { menjadi khalifah } \\
\text { diBumi }\end{array}$ & s.w.t & Swt. \\
\hline 6 & $\begin{array}{l}\text { Jakarta } \\
\text { merupakan kota } \\
\text { metropolitan } \\
\text { dimana kota } \\
\text { tersebut adalah } \\
\text { kota pusat } \\
\text { administrasif } \\
\text { bisnis } \\
\text { kenegaraan dan } \\
\text { lain lain, maka } \\
\text { dari itu kta } \\
\text { tersebut tidak } \\
\text { pernah luput dari } \\
\text { kesunyian } \\
\text { melainkan } \\
\text { banyakanya hilir } \\
\text { music disetiap } \\
\text { waktunya. }\end{array}$ & Bisnis, & Bisnis, \\
\hline 7 & $\begin{array}{l}\text { Jaringan internet } \\
\text { android pun jauh } \\
\text { lebih mudah dan } \\
\text { dilengkapi } \\
\text { dengan wifi } \\
\text { membuat } \\
\text { pengguna } \\
\text { android bisa } \\
\text { mengakses } \\
\text { jaringan ditempat } \\
\text { - tempat umum } \\
\text { tertentu. }\end{array}$ & $\begin{array}{l}\text { Ditempat } \\
\text { - tempat }\end{array}$ & $\begin{array}{l}\text { Di } \\
\text { tempat- } \\
\text { tempat }\end{array}$ \\
\hline 8 & $\begin{array}{l}\text { Di perkirakan, } \\
\text { hanya dinaikan } \\
\text { menjadi } \quad \text { Rp. } \\
6.500 \text { per liter. }\end{array}$ & $\begin{array}{l}\text { Rp. } \\
6.500\end{array}$ & $\begin{array}{l}\text { Rp6.50 } \\
0,00\end{array}$ \\
\hline 9 & $\begin{array}{l}\text { Banjir. Jika kita } \\
\text { mendengar kata } \\
\text { banjir, pasti yang } \\
\text { teringat dipikiran } \\
\text { kita adalah } \\
\text { Jakarta. }\end{array}$ & Banjir. & Banjir, \\
\hline
\end{tabular}

Tabel 3

Tabulasi Kategori Kesalahan

\begin{tabular}{|l|l|c|c|}
\hline \multicolumn{2}{|c|}{ KATEGORISASI KESALAHAN } & JUMLAH \\
\hline \multirow{2}{*}{ Kesalahan } & Penggunaan huruf & 17 & \multirow{2}{*}{26} \\
\cline { 2 - 3 } & Tanda baca & 9 & \\
\hline
\end{tabular}

Dari ketiga tabel di atas dapat diketahui beberapa kesalahan penggunaan huruf dan tanda baca mahasiswa Jurusan Manajemen Fakultas Eknmi dan Bisnis Universitas Islam Negeri Syarif Hidayatullah Jakarta bahwasannya jumlah kesalahan penggunaan huruf terdapat 17 kesalahan sedangkan kesalahan penggunaan tanda baca terdapat 9 kesalahan, total kesalahan huruf dan tanda baca mahasiswa sebanyak 26 kesalahan.

\section{Analisis Data}

Data yang didapatkan dari karangan persuasi siswa yang kemudian direduksi dengan kesalahan yang ditemui. Berikut peneliti mencoba untuk menganalisis data yang didapatkan;

\section{Contoh analisis kesalahan penempatan huruf kapital;}

Kalimat ke-1 (karya Azhar Ramadhan Margie)

Akhir-akhir ini kita sering melihat beritaberita di Televisi Tentang banjir yang melamda Ibukota jakarta.

Deskripsi: Kalimat di atas terdapat kesalahan dalam penempatan huruf kapital. Kata 'Televisi' 'Tentang' seharusnya tidak menggunakan huruf kapital. Dan kata 'jakarta' seharusnya menggunakan huruf kapital di awal kata menjadi 'Jakarta' karena kata terebut menunjukan tempat. Penulisan yang betul seharusnya "Akhirakhir ini kita sering melihat berita-berita di televise tentang banjir yang melanda di Ibukota Jakarta. 


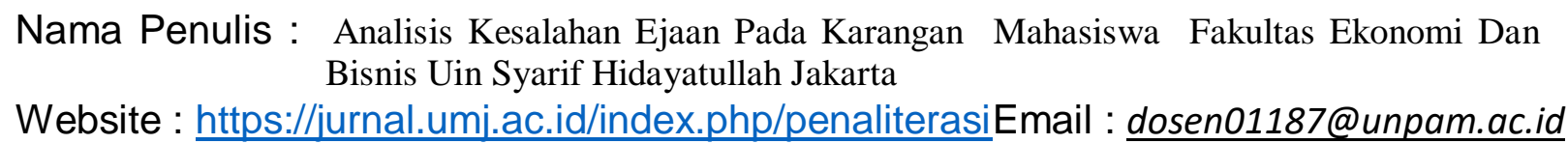

Kalimat Ke-1 (Karya Ahmad Jody)

Ruangan Berukuran $100 \times 90 \quad m$ ini sungguh nyaman ditempati Sebuah kursi kayu berwarna coklat dengan meja Kayu berada di tengah ruangan.

Deskripsi: kalimat di atas terdapat kesalahan penempatan huruf kapital, kata 'Berkuran' menunjukan kata verba yang tidak boleh diberi huruf kapital di awal kata, kata 'Sebuah' menunjukan kata numeralia yang berada ditengah kalimat yang bukan menunjukan tempat maka tidak boleh menggunakan huruf kapital di awal kata, kata 'Kayu' huruf awal pada kata tersebut tidak boleh menggunakan huruf kapital. Jadi seharusnya kalimat tersebut tertulis seperti: "Ruangan berukuran $100 \mathrm{x}$ $90 \mathrm{~m}$ ini sungguh nyaman ditempati sebuah kursi kayu berwarna coklat dengan meja kayu berada di tengah ruangan."

Kalimat ke-2 (karya Lutfi Wijaya)

Disorotinya oleh terangnya lampu jalan, pengendara disuguhi para pengamen yang dari tadi menyanyikan Lagu tanpa lelah, Tidak jelas penyebab kemacetan ini yang membuat antrean kendaraan begitu panjang.

Deskripsi: Kalimat di atas terdapat kesalahan penempatan huruf kapital, kata 'Lagu' seharusnya tidak menggunakan huruf kapital di awal kata, kata 'Tidak' seharusnya tidak menggunakan huruf kapital karena kata tidak tersebut hadir setelah tanda baca koma (,), jika setelah koma kata huruf pertama pada kata tidak boleh menggunakan huruf kapital. Penulisan yang benar seharusnya "Disorotinya oleh terangnya lampu jalan, pengendara disuguhi para pengamen yang dari tadi menyanyikan lagu tanpa lelah, tidak jelas penyebab kemacetan ini yang membuat antrean kendaraan begitu panjang."
Salah satu alasan terjadinya banjir adalah sampah di indonesia yang menutup jalur air hujan yang mengakibatkan air tersendat dan naik ke permukaan.

Deskripsi: Dalam kalimat di atas penggunaan kata 'indonesia' seharusnya diberikan huruf kapital pada awal kata karena kata 'Indonesia' menunjukan kata tempat. sehingga penulisan yang benar adalah 'Indonesia'

Kalimat ke-2 (karya Lutfi Wijaya)

Kemacetan nampaknya sudah menjadi hal yang biasa terlihat di jalanan Ibukota jakarta.

Deskripsi: penulisan kata 'jakarta' seharusnya menggunakan huruf kapital di awal, seperti 'Jakarta'

\section{Contoh Analisis Kesalahan Penggunaan Tanda Baca}

Kalimat ke-1. (Karya Vigr Risay Setiawan) Jakarta merupakan kota metropolitan dimana kota tersebut adalah kota pusat administrasif bisnis, kenegaraan dan lain lain, maka dari itu kta tersebut tidak pernah luput dari kesunyian melainkan banyakanya hilir music disetiap waktunya. Deskripsi: pada kalimat di atas terdapat tiga kesalahan tanda baca. Pertama, keslahan tanda baca koma yang sebelumnya diberikan spasi. Kedua, kata 'dan lain lain' yang tidak menggunakan tanda hubung (-). Ketiga, setelah kata 'dan lain lain' seharusnya menggunakan tanda titik (.) karena kata sesudahnya menunjukan kalimat yang baru, yaitu:' maka dari itu kta tersebut tidak pernah luput dari kesunyian melainkan banyakanya hilir music disetiap waktunya.' Yang merpakan kalimat kedua dalam paragraf.

Kalimat ke-7 (Karya Ida Juraida) 
Jaringan internet android pun jauh lebih mudah dan dilengkapi dengan wifi membuat pengguna android bisa mengakses jaringan ditempat - tempat umum tertentu.

Deskripsi: Kalimat di atas terdapat keslahan tanda baca penggunaan tanda hubung (-) pada kata 'di tempat - tempat' yang seharusnya kata tersebut tidak diberikan spasi di sekelilingnya. Penggunaan tanda hubung yang benar adalah 'di tempattempat'

Kalimat ke-2 (Karya Rizki Ananda Putra) Di perkirakan, hanya dinaikan menjadi $R p$. 6.500 per liter.

Deskripsi: kalimat di atas mengalami kesalahan tanda baca titik (.) pada penulisan Rp (rupiah). Menurut pedoman Ejaan Yang Disempurnakan, penulisan $\mathrm{Rp}$ yang didampingi oleh nominal tidak menggunakan tanda titik (.). jadi penulisan yang benar adalah seperti 'Rp6.500,00'.

Kalimat ke-1 (Karya Robiatul Adawiyah) Banjir. Jika kita mendengar kata banjir, pasti yang teringat dipikiran kita adalah Jakarta.

Deskripsi: kalimat di atas mengalami kesalahan penggunaan tanda baca (.). Di awal paragraf hanya ada sebuah kata 'banjir', tanda titik penggunaannya adalah untuk intonasi akhir sebuah kalimat, 'banjir' adalah sebuah kata bukan kalimat. Jadi seharusnya setelah kata 'banjir' jika ingin diberi penekananpun tidak boleh tanda titik, akan tetapi berilah tanda koma (,).

\section{D.Temuan Data}

Berdasarkan hasil analisis dibantu dengan tabel analisis, maka peneliti menemukan data bahwa adanya kesalahan penggunaan huruf dan tanda baca yang dilakkan mahasiswa Jurusan Manajemen Fakultas Ekonmi dan Bisnis Universitas Islam Negeri Syarif Hidayatullah Jakarta. yaitu penggunaan huruf kapital yang tidak tepat, adanya huruf kapital di tengah kalimat dan tidak adanya huruf kapital di awal kata tempat, di mana penggunaan kata tempat harus diberi huruf kapital di awal kata.

Penggunaan tanda baca pada penulisan bnyak yang mengalami kesalahan pada tanda titik (.) dan koma (,). Di mana penggunaan kata titik dan koma sellau didahului oleh spasi. Juga penggunaan tanda hubung (-) yang dikelilingi oleh spasi, ada pula penggunaan tanda (.) untuk sebuah kata, padahal gunanya titik adalah untuk memberikan intnasi akhir di penulisan pada suatu kalimat.

\section{KESIMPULAN}

$\mathrm{D}$ ari pembahasan yang telah dipaparkan dalam bab sebelumnya, dapat ditarik beberapa kesimpulan yakni:

1. Terdapat 26 kesalahan yang terdiri dari 17 kesalahan penggunaan huruf kapital dan 9 kesalahan penggunaan tanda baca yang dilakukan oleh responden mahasiswa jurusan Manajemen Fakultas Ekonomi dna Bisnis Universitas Islam Negeri Syarif Hidayatullah Jakarta.

2. Kesalahan penggunaan huruf kapital paling banyak terdapat pada jenis penggunaan huruf kapital untuk menunjukan nama tempat. Sedangkan kesalahan tanda baca terbanyak ditemukan pada penggunaan tanda titik dan koma.

3. Faktor penyebab responden melakukan kesalahan adalah faktor performansi, yakni kurangnya pelatihan dan konsentrasi, ketelitian dan ketergesa- 
Nama Penulis : Analisis Kesalahan Ejaan Pada Karangan Mahasiswa Fakultas Ekonomi Dan Bisnis Uin Syarif Hidayatullah Jakarta

Website : https://jurnal.umj.ac.id/index.php/penaliterasiEmail : dosen01187@unpam.ac.id

gesaan pada saat mengerjakan test, juga kurangnya frekuensi latihan yang dilakukan responden mengenai aturan penggunaan huruf kapital dan tanda baca khususnya dalam menulis karangan persuasi bahasa Indonesia.

\section{UCAPAN TERIMA KASIH}

D enulis ucapkan terima kasih kepada 1 Allah SWT sehingga penelitian ini dapat terlaksana. Terima kasih juga penulis ucapkan kepada semua pihak yang sudah membantu mulai dari SMPN 118 Jakarta tempat penulis melakukan penelitian dan teman -teman di Universitas Bhayangkara Jakarta Raya tempat penulis mengabdi sebagai dosen.

\section{REFERENSI}

Arikunto, Suharsimi. 2006. Prosedur Penelitian(Jakarta: Rineka Cipta.

Badudu, J.S. 1988. Inilah Bahasa Indonesia yang Benar. Jakarta: PT. Gramedia.

Brown, H. Douglas. 1994. Principles of Language Learning and Teaching San Francisco: Prentince Hall Regents.

Corder, S.P. 1981. Eror Analysis and Interlanguage Oxford: Oxford University Press

Ernawati, Waridah. 2009. Ejaan Yang Disempurnakan dan Seputar Kebahasaan-Indonesia. Jakarta: Kawan Pustaka.

Gani, Ramlan A. dan Mahmudah Firiyah Z.A. 2010. Disiplin Berbahasa Indonesia, Jakarta: FITK Press, cet ke-1

Gorys, Keraf. 1997. Komposisi. Ende Flores: Nusa Indah.

James, Carl. 1998. Eror in Language Learning and Use. London: Longman.
Richards, Jack C. 1974. Error Analysis: Perspective on Second Language Acqusition. London: Longman.

Subyakto, Sri Utari-Nababan. 1994. Analysis Kontrastif dan Kesalahan: Suatu Kajian dari Sudut Pandang Guru Bahasa. Jakarta: PPs IKIP Jakarta.

Sugiyono. 2007. Memahami Penelitian Kualitatif. Bandung:Alfabeta

Supriyadi. 1986. Buku Materi Pokok Analisis Kesalahan Berbahasa: PINA2235/2SKS/Modul 1-3 Jakarta: Karunika Jakarta Universitas Terbuka.

Sriyanto. 2016. Ejaan. Jakarta: Pusat Pembinaan 